\title{
2.3 \\ INREDNINGS- OCH MÖBELMÅLERI \\ I OVANÅKER OCH DELSBO
}

\author{
Johan Knutsson
}

Det interiörmåleri från 1700-talet som bevarats i Voxnandalen i södra Hälsingland har stilistiskt mycket gemensamt med det som ungefär samtidigt tillkom i Delsbo och Bjuråkers socknar i norra delen av landskapet och i Svärdsjö och Envikens socknar i Dalarna. De anmärkningsvärda likheterna mellan de tre områdenas måleri väcker frågor. Var har måleriet först uppstått och hur har det utvecklats i växelverkan med övriga områden? Och speglar det bevarade materialets spridning den ursprungliga utbredningen? Detta kapitel bygger vidare på de två artiklar om möbelmåleri i Dellenområdet och inredningsmåleri i Voxnandalen och norra Hälsingland som tidigare publicerats i Hälsingerunor 2014 och 2016. Konnässörskapsanalysen av handlag och detaljer samt analysen av förekommande identifierbara stilhistoriska inslag har nu kompletterats med de under projektet inhämtade analyserna av material och teknik.

\section{Voxnandalens interiör- och möbelmåleri}

Voxnandalens folkliga möbel- och inredningsmåleri från 1700-talet blev tidigt föremål för folklivsforskares och hembygdsforskares intresse. Sigurd Erixon noterar den rika förekomsten av detta måleri i "nästan alla mera betydande gårdar i Edsbyn och utbyarna däromkring" (Erixon 1937:188). Vad dokumentationen beträffar är vi alltså förhållandevis väl försedda. Forskningsinsatserna är mer ojämnt fördelade.

\section{Dokumentation och forskning}

På 1940-talet genomfördes genom Ovanåkers hembygdsförening en inventering av Voxnandalens interiörmåleri. Resultatet av undersökningen finns nu på Edsbyns museum. Områdets 1700-talsmåleri hör 
till det som fotodokumenterats inom ramen för det inventeringsprojekt som på 1990-talet genomfördes på initiativ av Kerstin Sinha vid Ljusdalsbygdens museum. Detta bildmaterial förvaltas av Alfta respektive Ovanåkers hembygdsföreningar och den senare sammanställningen inkluderar även den nyligen bortgångne hembygdsforskaren Gustav Olanders foton och kommentarer.

Det tidiga måleriet från 1500- och 1600-talen, som fick ordentlig uppmärksamhet i och med trossbottenfyndet i Alfta på 1960-talet, har omsorgsfullt beskrivits och analyserats av Maj Nodermann (Nodermann 1965, 1997). Även 1800-talets måleri i södra Hälsingland har satts in i sitt sammanhang (Nylander 2003). Men tiden däremellan är mer summariskt behandlad. Och någon mer djupgående forskning om 1700-talets måleri, baserad på den insamlade dokumentationen, har knappast skett.

\section{Interiörmåleri av Ovanåkersskolan - namngivna målare och deras verk}

Av det måleri av Ovanåkerskaraktär som bevarats utmärker sig några fynd och miljöer för ett särskilt stort källvärde. 1735 års väggmåleri från gården Per-Ers i Hamre, Ljusdals socken, och det fragmentariskt bevarade gavelröstet i Nygårds i Vängsbo, Ovanåkers socken, från 1737 är exempel på tidiga daterade verk. Gården Smens i Edsbyn har en central betydelse i sammanhanget, då den tillhörde en av måleriets tidigast kända utövare, Jonas Ericsson, eller Jonas Ersson. Bland de bevarade väggfälten därifrån ingår en målad krans med årtalet 1771 tillsammans med målarens och hans hustrus initialer. Ol-Mårs, Kyrkbyn i Alfta socken, är ett exempel på en gård som har en i sin helhet bevarad rumsinredning - om än restaurerad.

Det i Nygårds bevarade interiörmåleriet är utfört direkt på gavelröstets timmergavelfält. Vid en påbyggnad av huset med en andra våning i slutet av 1800-talet har man återanvänt timret från bottenvåningens gavelrösten, vilket innebär att det målade gavelfältet nu återfinns på vinden ovanför den påbyggda våningen (se fig. 1). Det målade gavelfältet i Nygårds från 1737 har av Olanders attribuerats till Eric Jonsson, född i slutet av 1600-talet och av Olanders identifierad som en av de första i socknen att tillämpa detta måleri (Olanders 1996). Olanders kallar honom Eric Ersson, ett namn som felaktigt anges i Ovanåkers släktbok från 1940-talet (Wahlund 1945).

Av 1735 års måleri i Per-Ers i Hamre, Ljusdals socken, är merparten av den på duk målade inredningen kvar på gården men sedan länge 


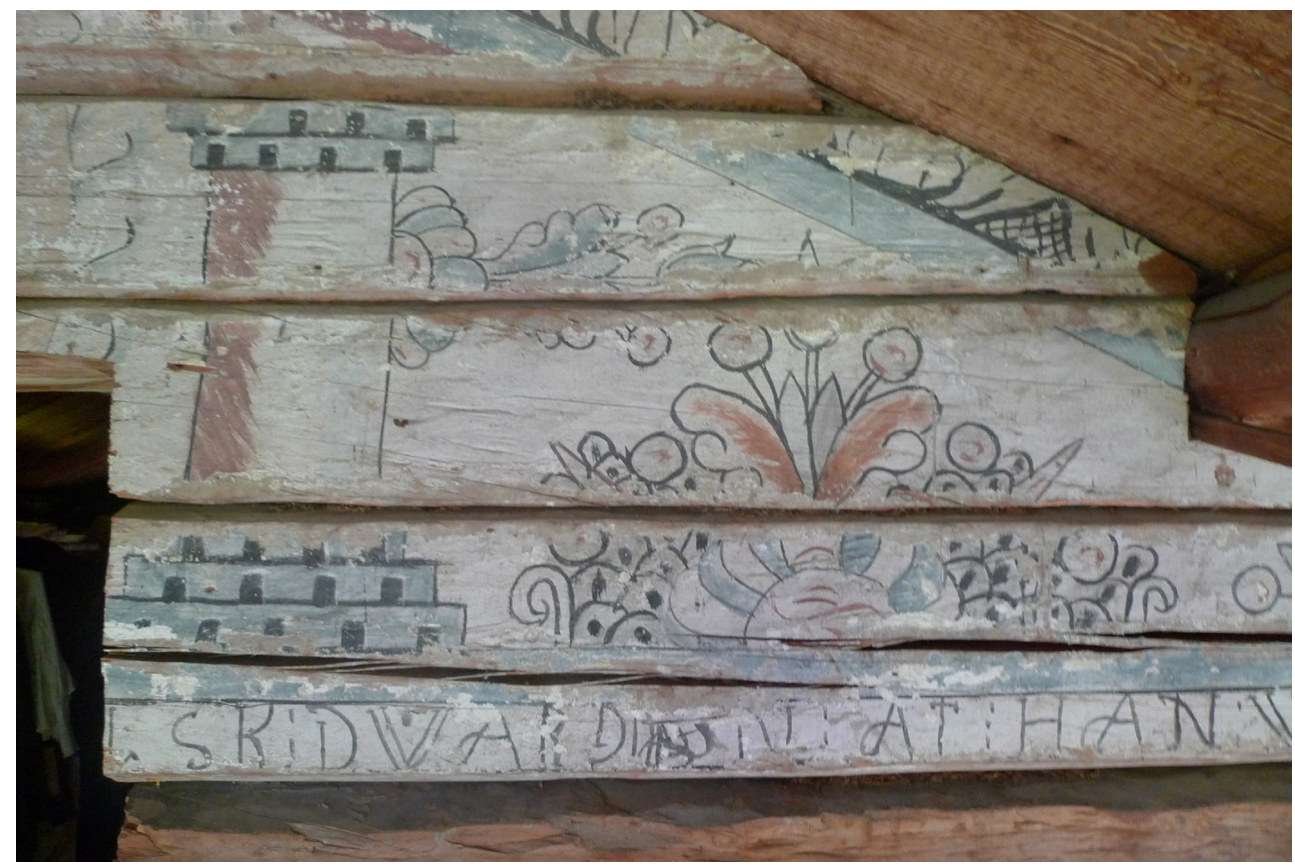

Figur 1 (2.3.1):

Måleriet från 1737, i Nygårds, Vängsbo i

Ovanåker, är valhänt och spretigt målat direkt på timret. Foto: Johan Knutsson.

Figur 2 (2.3.2): Detta måleri på grunderad väv kommer från Per Ers-gården i Hamre by, Ljusdal. Delen med dateringen 1735 och ytterligare ett par delar, ingår i Ljusdalsbygdens museums samlingar. Foto: Jan Eng.

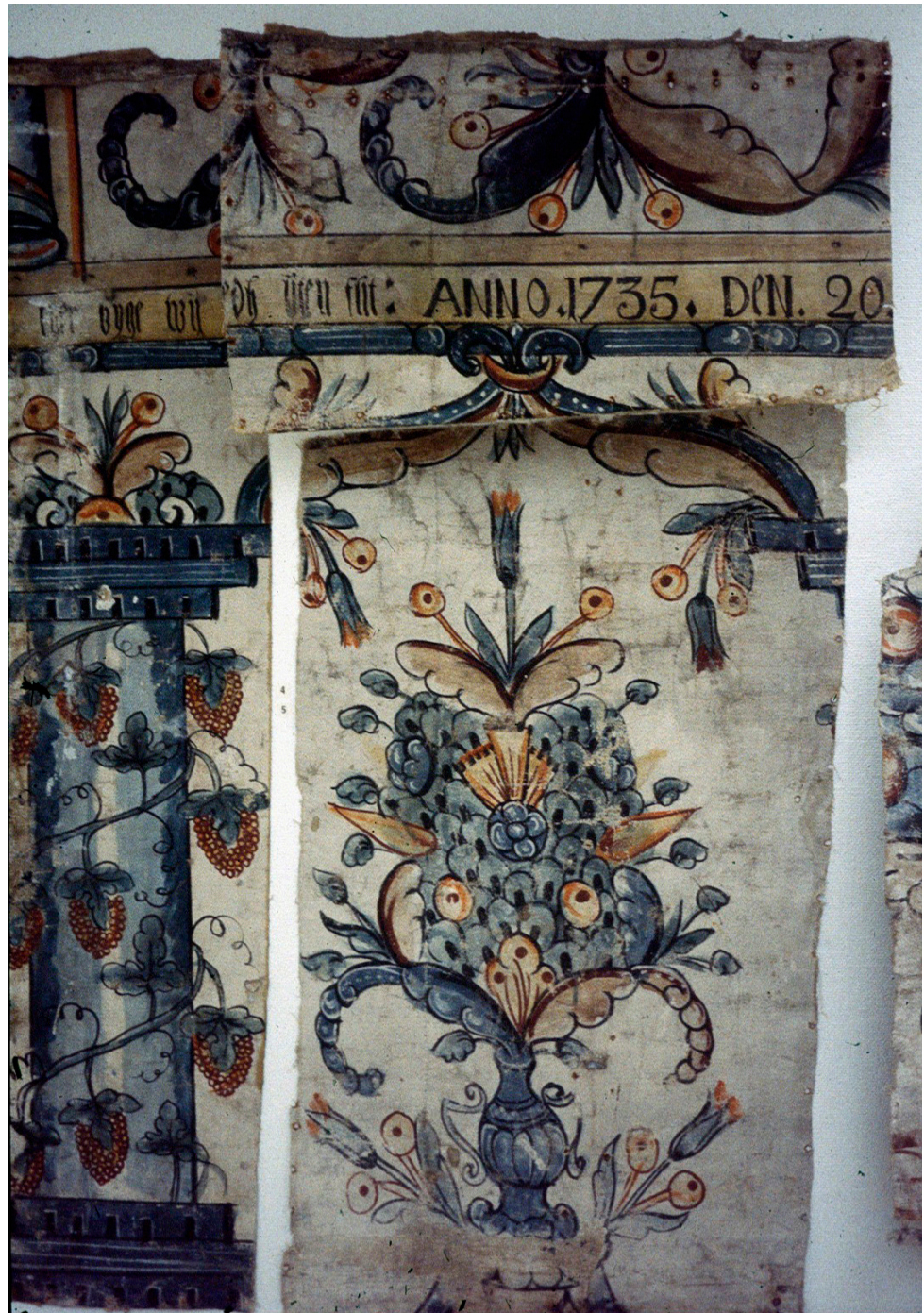




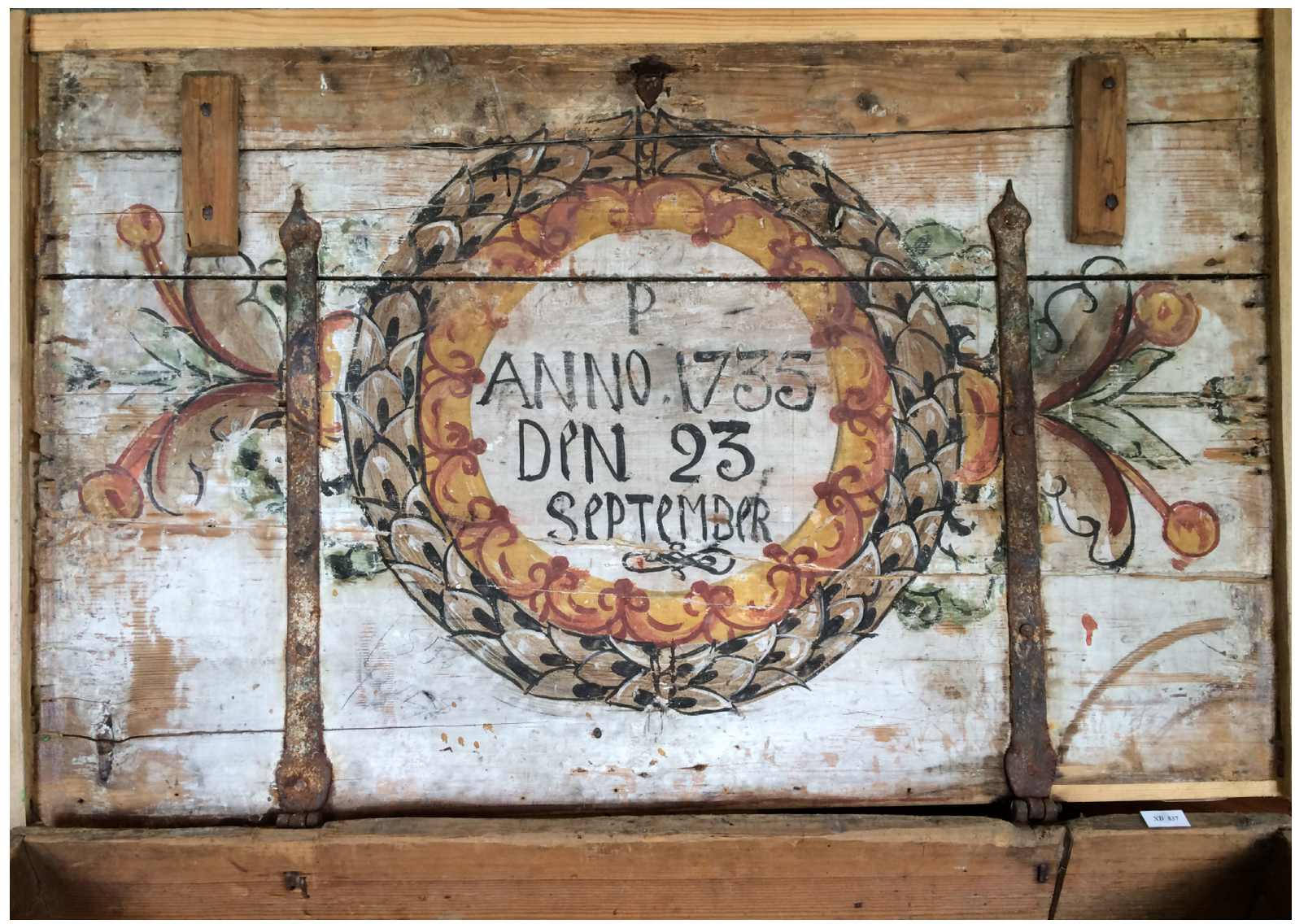

nedtagen (se fig. 2). Flera av delarna har återanvänts för ett senare måleri på dukens baksida. Partiet med årtalet 1735 samt ytterligare ett par delar finns bevarade på Ljusdalsbygdens museum (inv nr LjM 9230). ${ }^{16}$ Stilistiskt står måleriet från Per-Ersgården nära gavelfältet från 1737 . Men Per-Ersgårdens måleri är betydligt mer flyhänt och skickligt utfört än det i Vängsbo, och kan knappast vara utfört av samma hand. En materialteknisk analys har visat att det blå i Per-Ersgårdens måleri är indigo. ${ }^{17}$

Till gården Per-Ers interiörmåleri kan man länka måleriet på insidan av locket till en kista på Delsbo forngård, med samma målade datering, 1735 (se fig. 3). De slående likheterna i utförandet mellan måleriet på denna kista och väggfälten från Per-Ers, både ifråga om motiv, mönster och handlag, inte minst vad siffror och bokstäver beträffar, har setts som indikation på att de kan vara utförda av samma hand. ${ }^{18}$

16. Se Sinha \& Folkesdotter 2002:28f.

17. Analysen utförd av Lars Hälldahl, på initiativ av Kerstin Sinha, Ljusdalsbygdens museum.

18. Tack till Anders Assis, Ljusdalsbygdens museum, för denna observation.
Figur 3 (2.3.3): Kista med ett måleri på lockets insida som stilistiskt står mycket nära måleriet från Per Ers-gården och med samma datering 1735. Delsbo forngård. Foto: Johan Knutsson. 


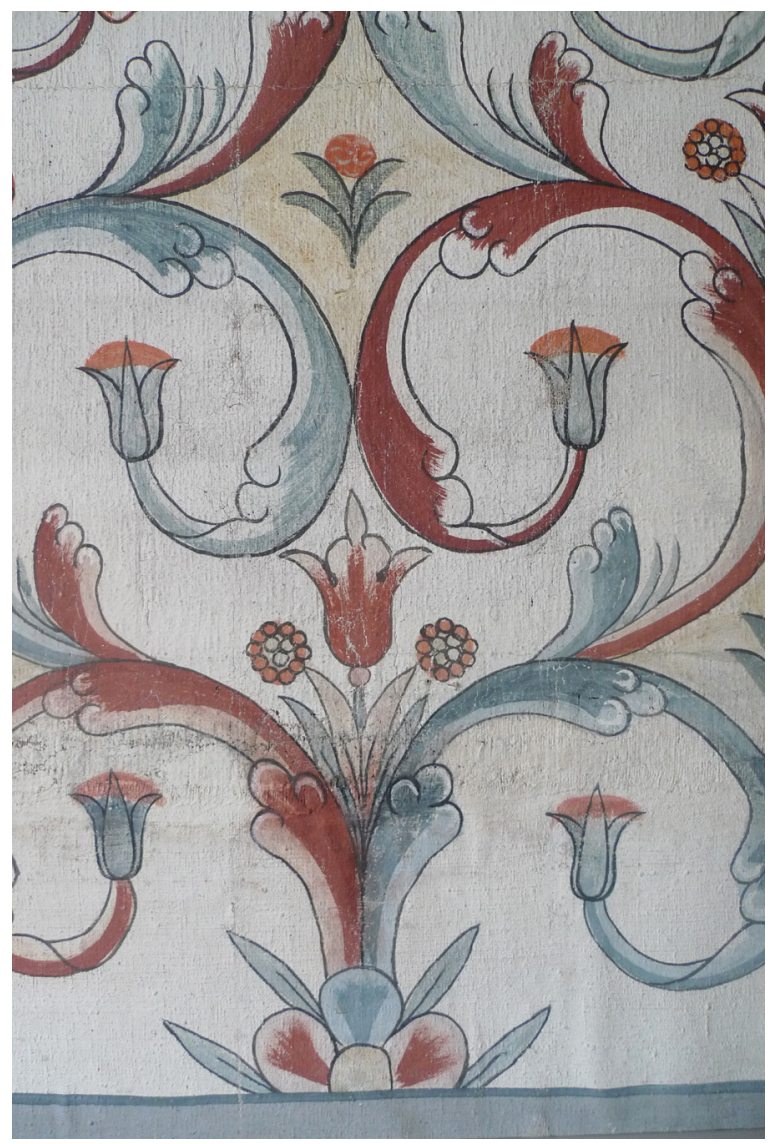

Vad Voxnandalens inredningsmåleri beträffar lanserade Sigurd Erixon inga namn. Det gjorde däremot Manne Östlund. Den målare som Erixon kallar "Ovanåkersmålaren" och som ibland gått under namnet "Ovanåkermästaren" identifierar Östlund som Jonas Eriksson (1730-1806) (Östlund 1953:64) - son till den ovannämnde Eric Jonsson. I husförhörslängden kallas han "målare".

Om osäkerheten är stor beträffande vem eller vilka som står bakom 1730-talets måleri är läget alltså något ljusare när det gäller generationen efter och det måleri som kan knytas till Jonas Eriksson född 1730. Initialerna IES (för Jonas Eriksson) och KOD (för hustrun Kerstin Olsdotter) och årtalet 1771 inom en målad krans i den gård, Smens, som Jonas Eriksson övertog från sina föräldrar (Olanders 1996:85) är i princip att betrakta som en signering (se fig. 4). Genom husförhörslängden kan vi bekräfta Jonas

Figur 4 (2.3.4): Stora delar av en rumsinredning i det hus där målaren Jonas Ersson bodde har bevarats. Kransen med dateringen 1771 och initialerna för målaren och dennes hustru visar samma sorts blomsteroch bladformer som i annat måleri, attribuerat till Jonas Ersson. Foto: Lars Nylander
Erikssons verksamhet som målare under perioden 1778-1792. Det vore långsökt att tro något annat än att interiörmåleriet $\mathrm{i}$ hans eget hus utförts av honom själv.

Det mest magnifika exemplet på bevarat måleri i Ovanåkersstil, möjligen utfört av Jonas Eriksson i samarbete med sonen Eric Jonsson (se vidare nedan), finns i gården Ol-Mårs i Alfta kyrkby (se fig. 5 och 6). Denna i sin helhet bevarade - om än restaurerade - interiör har aldrig lämnat det hus för vilket den skapades, men flyttades på 1990-talet till dess nuvarande plats på husets övervåning som tillkom vid mitten av 1800-talet.

I likhet med Jonas Eriksson själv kallas dennes son Eric Jonsson (1755-1843) i husförhörslängderna "målare". De noteringarna infaller 1792-1810. Något signerat måleri av honom har hittills inte påträffats, men ett målat väggfält i Edsbyns museum är attribuerat 

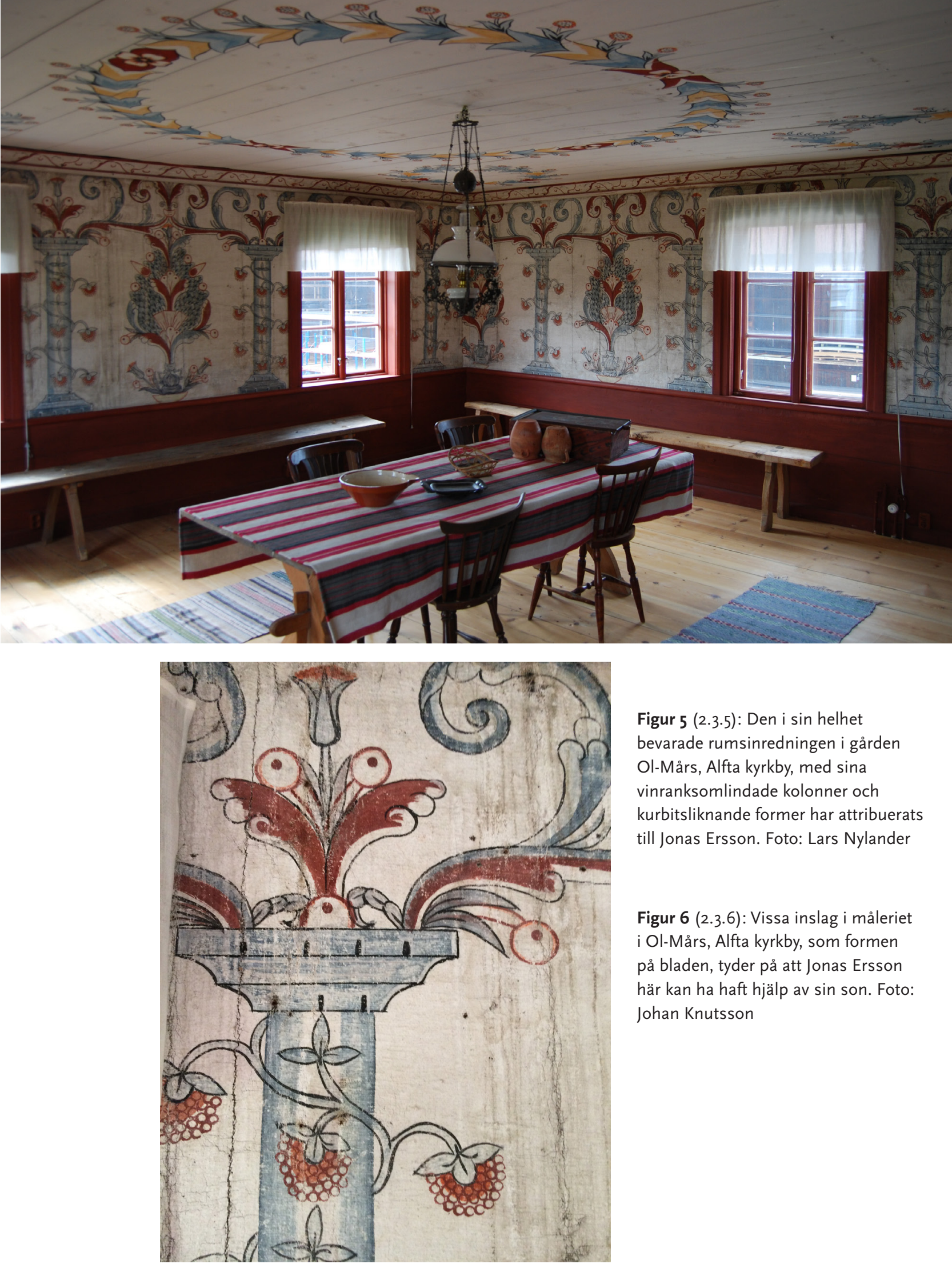

Figur 5 (2.3.5): Den i sin helhet bevarade rumsinredningen i gården Ol-Mårs, Alfta kyrkby, med sina vinranksomlindade kolonner och kurbitsliknande former har attribuerats till Jonas Ersson. Foto: Lars Nylander

Figur 6 (2.3.6): Vissa inslag i måleriet i Ol-Mårs, Alfta kyrkby, som formen på bladen, tyder på att Jonas Ersson här kan ha haft hjälp av sin son. Foto: Johan Knutsson 
till honom. Mycket tyder på att Eric Jonsson samarbetade med sin far. $\mathrm{Vi}$ återkommer till det.

\section{Ovanåkersmåleriets ursprung och stildrag}

Ovanåkersmåleriet har sina rötter i områdets interiörmåleri från 1500- och 1600-talen. Här finns också ett samband med kyrkornas utsmyckning, som tidigt framhållits, först av Sigurd Erixon som påpekar måleriets "nära frändskap med mellersta Norrlands kalkmåleri under vasatiden" (Erixon 1937:193) och senare av Manne Östlund som särskilt nämner de markerade konturerna, den begränsade färgskalan och ytmässigheten (Östlund 1953:54). Många kyrkors medeltida måleri överkalkades under 1700-talet men fram till dess fanns de kvar till allmänt beskådande och inspiration.

Kännetecknande för 1700-talsmåleriet i Ovanåker och Alfta, liksom för det samtida i Delsbo och Bjuråkers socknar, är de ihoprullade akantusrankorna, eller "akantuskrokarna", som Östlund och senare Olanders kallar dem. Även blomsteruppsättningarna i stiliserade former som erinrar om grankottefjäll eller påfågelsfjädrar liksom lagerbladskransar hör till de särdrag som är vanliga i båda områdena.

Det mest karaktäristiska för just Ovanåker och Alfta socknars 1700-talsmåleri är kolonner omlindade med vindruvsrankor. Motivet har framhållits som en för Ovanåker och Alfta specifik företeelse (Decorated Farmhouses 2011:85) även om det också, som vi ska se, sparsamt förekommer i landskapets norra del. Det förekommer i måleriet från Per-Ers i Ljusdal från 1735. Därefter dyker det upp med jämna mellanrum, genom hela 1700-talet och in på 1800-talet. Förebilden kan ha varit Ovanåkers altaruppsats från 1690-talet, beställd och utförd för socknens tidigare kyrka och numera uppsatt på en sidovägg i den nuvarande kyrkan. Enligt Olof Broman utfördes den av "Snickaren Måns Jonsson ifrån Hudicksvall, på samma sätt som samma stads kyrkas altaretafla" (citerat efter Hamberg 1974, not 64). Måns Jonsson var av allt att döma identisk med den Måns Snickare från Hudiksvall som nämns i andra kyrkors räkenskaper (Aronsson 2014). Måns Snickare kan i sin tur ha inspirerats av de vinranksomlindade kolonner med kapitäl i kompositaordning som den nordtyske bildhuggaren Ewerdt Friis utförde för Kristine kyrka i Falun 1669 och Heliga Trefaldighets kyrka i Gävle 1662. Och Friis kan i sin tur ha tagit över motivet från den i början av 1600-talet i Nordtyskland verksamme bildhuggaren Hans Gudewerdt den yngre. 
Personliga handlag och manér attribuering utifrån frihandsmåleri och verktygsspår

Jonas Erikssons personliga manér går att identifiera och beskriva tack vare det i Smens bevarade och attribuerbara måleriet. Målaren har med säker hand avbildat hallonliknande vindruvsklasar med hallonkärnorna eller vindruvorna avbildade som små cirklar regelbundet placerade i kompositionen. Bladen är sirligt flikiga (se fig. 7). I Jonas Erikssons repertoar ingår även blommor sammansatta av cirklar som liknar cirklarna i vindruvsklasarna.

Det till sonen Eric Jonsson attribuerade måleriet utmärker sig för en annan detaljutformning med hallonkärnorna eller vindruvorna oregelbundet placerade och markerade med något större cirklar - som på väggfälten i Ovanåkers hembygdsförenings samlingar, vid Edsbyns museum och i hembygdsgården Mårtes. Bladen är betydligt enklare utförda utan flikar. Så är bladen utformade i Ol-Mårs, vilket kan tyda på att Jonas Ericsson i detta arbete kan ha tagit hjälp av sin son - något som i så fall innebär att interiören kan ha tillkommit tidigast i början eller vid mitten av 1770-talet, när Eric Jonsson uppnått 15-20-årsåldern.

Förmodligen har utövarna av Ovanåkersmåleriet varit fler än de hittills identifierade. Ett färde väggfält i Edsbyns museum är målat i ett handlag som trots likheter i stort ändå tydligt avviker från de två nämnda målarnas handlag i detaljerna.

\section{"Äppelmålaren" och andra okända möbelmålare}

Ovanåkersskolans målare har sannolikt varit både inrednings- och möbelmålare. Gustaf Olanders var övertygad om att framför allt Jonas Ericsson har målat möbler och framhåller "kistor dekorerade med akantusslingor" (Olanders 1996). Hittills har det dock inte gått att med

Figur 7 (2.3.7): Detalj av Jonas Erssons måleri. Foto: Johan Knutsson. 


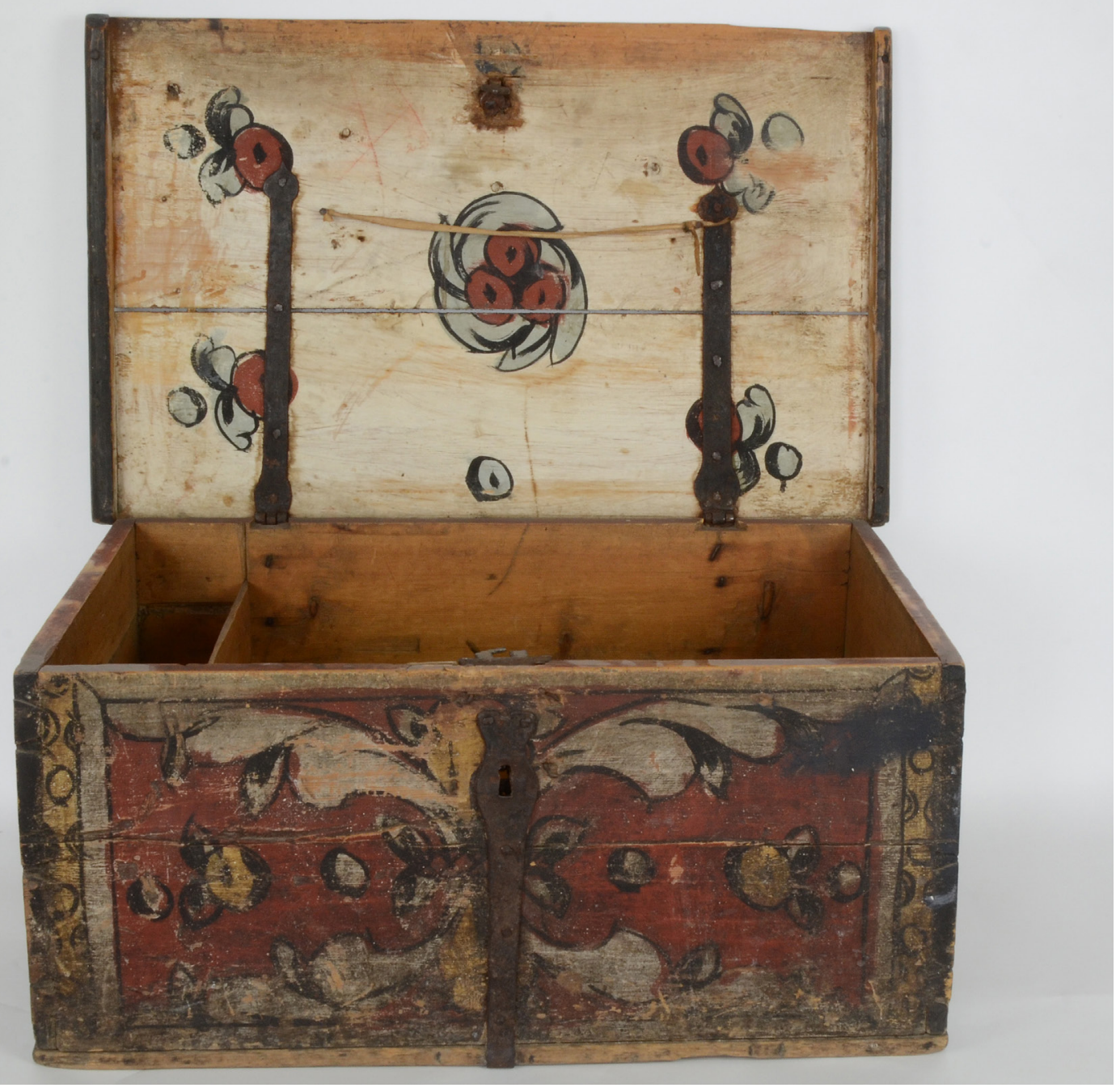

Figur 8 (2.3.8): Kista med målad dekor i form av akantusblad och stiliserade marmoreringsmönster längs framsidans kanter. Kistan kommer från Koldemo, Arbrå. Äppelmotiven på locket insida har gett upphov till pseudonymen Äppelmålaren (HM 17 644). Foto: Bonny Sjöblom säkerhet attribuera något möbelmåleri till denne målare. Inget signerat möbelmåleri har påträffats.

En grupp kistor och skrin - bevarade exemplar finns i Nordiska museets (NM 189109; NM 193527), Hälsinglands museum (HM 17644; HM 23835) och Edsbyns museums samlingar (XOV 3130) - har en mycket säregen dekor. Det mest egenartade är de vertikala bårderna med ett slags stiliserat ådrings- eller marmoreringsmönster längs framsidans kanter (se fig. 8). Förekomsten av det återkommande äppelmotivet på lockets insida har gett upphov till pseudonymen Äppelmålaren för denna än så länge anonyma målare. Kanske var de flera. Med viss möda går det att urskilja flera handlag.

Utsidans måleri ligger ibland, i likhet med vad som även kan förekomma i Reuters möbelmåleri, ovanpå en tunn kritgrundering. Avsikten med krederingen har inte varit att åstadkomma ett jämnt underlag. 
Därtill är den alltför tunn. Snarare har det handlat om att förse ytan med en ljus bakgrundsfärg som bättre framhäver lystern i motivens färger. ${ }^{19}$ Allmogemålarna använde ibland en kritgrund som underlag för magert, matt måleri - mer sällan för oljefärg som det här är fråga om. Det kan tyda på att målaren haft kontakter med skråmålarna i Söderhamn eller någon annan stad. Eller så föll det sig naturligt för en målare vars huvuduppgift var att måla bonader, där bottenfärgen var vit och preparerades med kritgrund.

Det relativt stora antalet kistor, det hastiga manéret och det faktum att de smidda hörnbeslagen och gångjärnsbeslagen på lockets insida har tillkommit efter måleriet - hos andra samtida kistor brukar de smidda beslagen på insidan av locket vara övermålade med samma färg och mönster som den omgivande ytan - antyder att tillverkningen skett mycket rationellt. ${ }^{20}$ Målaren, eller målarna, förefaller ha jobbat snabbt och ibland till och med slarvigt med dålig synkronisering mellan färgfält och målade svarta konturer.

\section{Reuterskolans interiör- och möbelmåleri}

Gustaf Reuter hör till de mest kända allmogemålarna, inte bara i Hälsingland utan överhuvudtaget. Många interiörer har kunnat knytas till honom genom traderade uppgifter och genom signerade verk. Han har utpekats som frontfigur och fått ge namn åt en hel "skola".

\section{Dokumentation och forskning}

Efterhand har personuppgifterna kring Reuters ursprung och familj kunnat styrkas och kompletteras genom belägg i olika arkivhandlingar (Sandberg 2005). Men ännu saknas en monografi över denne "vårt lands förnämsta bygdemålare" som Erixon kallar honom (Erixon 1937:169). Och i stort sett okänd är hans verksamhet som möbelmålare.

Andra forskare som identifierat målarna inom Reuterskolan och deras verk är Jan Lundell och Åke Norberg, Maj Nodermann, Maj-Britt Andersson och Elvi Sandberg. Nodermann påbörjade ett omfattande arbete i avsikt att presentera Reuter med verkskatalog, kulturhistorisk kontext och analys av förlagor och inspirationskällor. En del av det materialet har tillvaratagits i arbetet med detta kapitel.

19. Tack till Ingalill Nyström för observationer och synpunkter.

20. Tack till Anders Assis, Ljusdalsbygdens museum, för denna observation. 
Interiörmåleri av Reuterskolan - namngivna målare och signaturer

Född i Västmanland upptas Gustaf Reuter (1699-1783) vid 22 års ålder i rullorna som korpral vid Delsbo kompani 1721 (Sandberg 2005; Nodermann 1998). År 1742 befordrades han till korpral. I allt större omfattning kom han att mellan kommenderingarna ägna sig åt interiör- och möbelmåleri, särskilt sedan han 1757 tagit avsked från det militära.

Reuter signerade sitt interiörmåleri med "G.R.", alternativt "G.Reuter" tillsammans med årtal eller med hela namnet "Gustaf Reuter". Ofta förekommer i anslutning till signaturen stjärnor i form av fyra korslagda streck, det vill säga åtta uddar, med punkter i mellanrummen. Motivet förekommer i både interiörmåleri och möbelmåleri som går att attribuera till Reuter.

Men Reuter var inte ensam om stjärnmotivet. Exakt samma stjärna, tillsammans med årtalet 1793, finns också i locket till en Delsbokista med nedåt och inåt sluttande sidor i Delsbo forngård. Det är tio år efter Reuters död. Det så kallade omegatecknet har ibland framhållits som ett sätt för Reuter att signera. Det förekommer i såväl interiörmåleri som i det möbelmåleri som på stilistiska grunder kan knytas till honom. Men inte heller detta motiv är helt unikt för honom.

Reuter har uppenbarligen varit verksam som målare åtminstone från 1730-talet, kanske rent av redan på 1720-talet. Det äldsta bevarade hittills kända interiörmåleriet av Reuter är daterat 1740. Det är ett gavelstycke från Hassela, nu i Hälsinglands museum (HM 765 ), signerat "G.R." och ansett som "det tidigast kända exemplet på Reuters trekonungaritt" (Lundell \& Norberg 1990:130; Nodermann 1984). Ett signerat väggfält ur denna svit har undersökts i projektet.

Andra tidiga verk av Reuter är en målning från Kramsta i Järvsö, daterad 1746 och signerad på samma sätt (Erixon 1937:178). I Jens Ors-gården, Bjuråkers forngård, finns i förstukammaren ett måleri med dateringen 1755. Det är inte signerat men tillskrivet Reuter (Lundell \&

Figur 9 (2.3.9): I det av Gustaf Reuter signerade och 1760 daterade måleriet i Frisbogården, Bjuråkers forngård, ingår motivet Jacobs stege. Foto: Lars Nylander. Norberg 1990:133) - en attribuering som kanske kan diskuteras med tanke på den svaga figurteckningen som så markant avviker från annat av Reuter signerat måleri. I Frisbogården, samma forngård, finns på övervåningen en inredning, daterad 1760 , som signerats av honom och det är svårt att föreställa sig att samma målare står bakom det valhänta måleriet i Jens Ors-gårdens förstukammare (se fig. 9).

Sin sista inredning i Delsbo signerar Reuter 1775. För en gård i Västansjö, Bjuråker, gjorde han en svit signerad "GR" och daterad 1776 (Lundell \& Norberg 1990:130). Vid 79 års ålder utför han ett av sina 

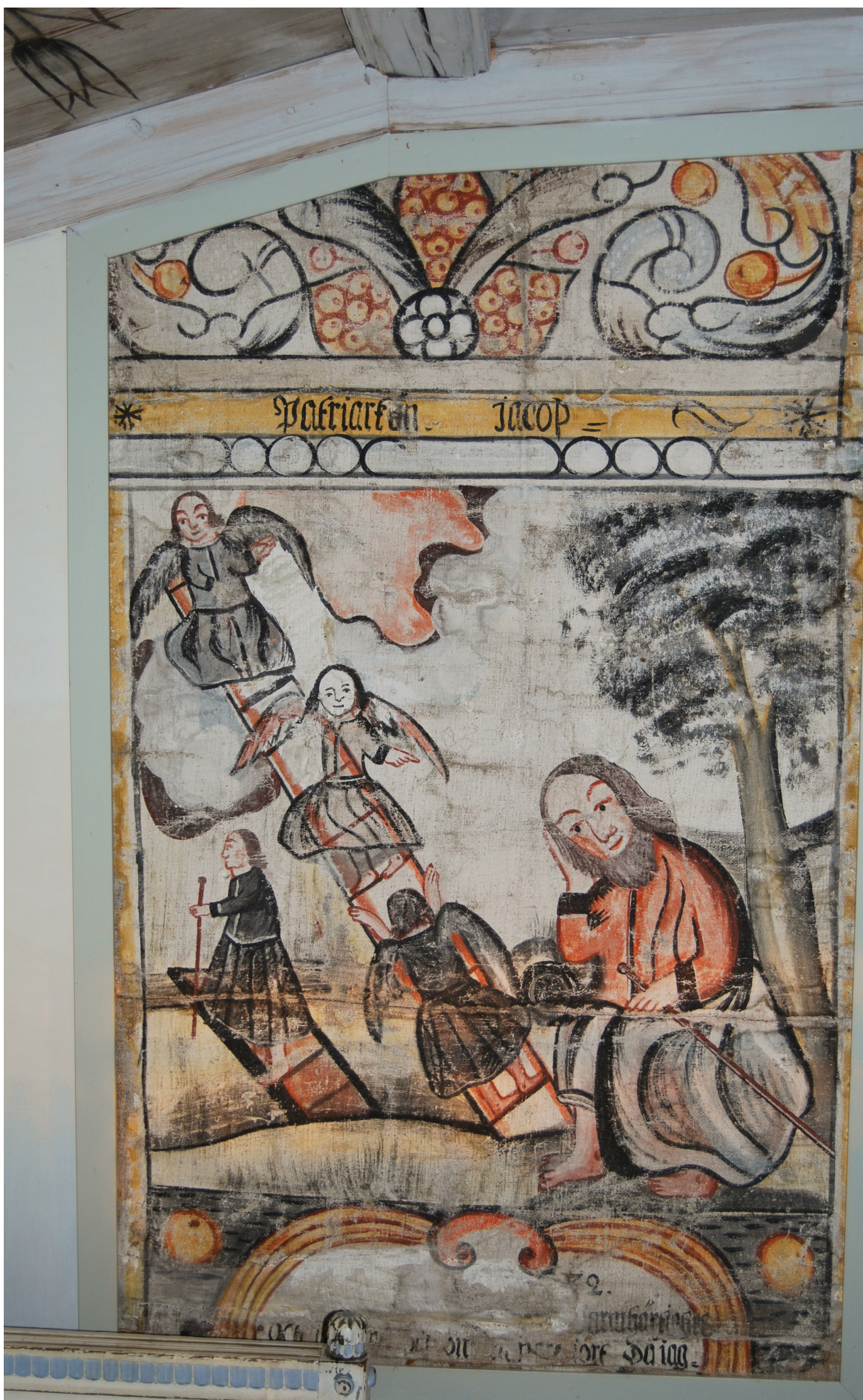


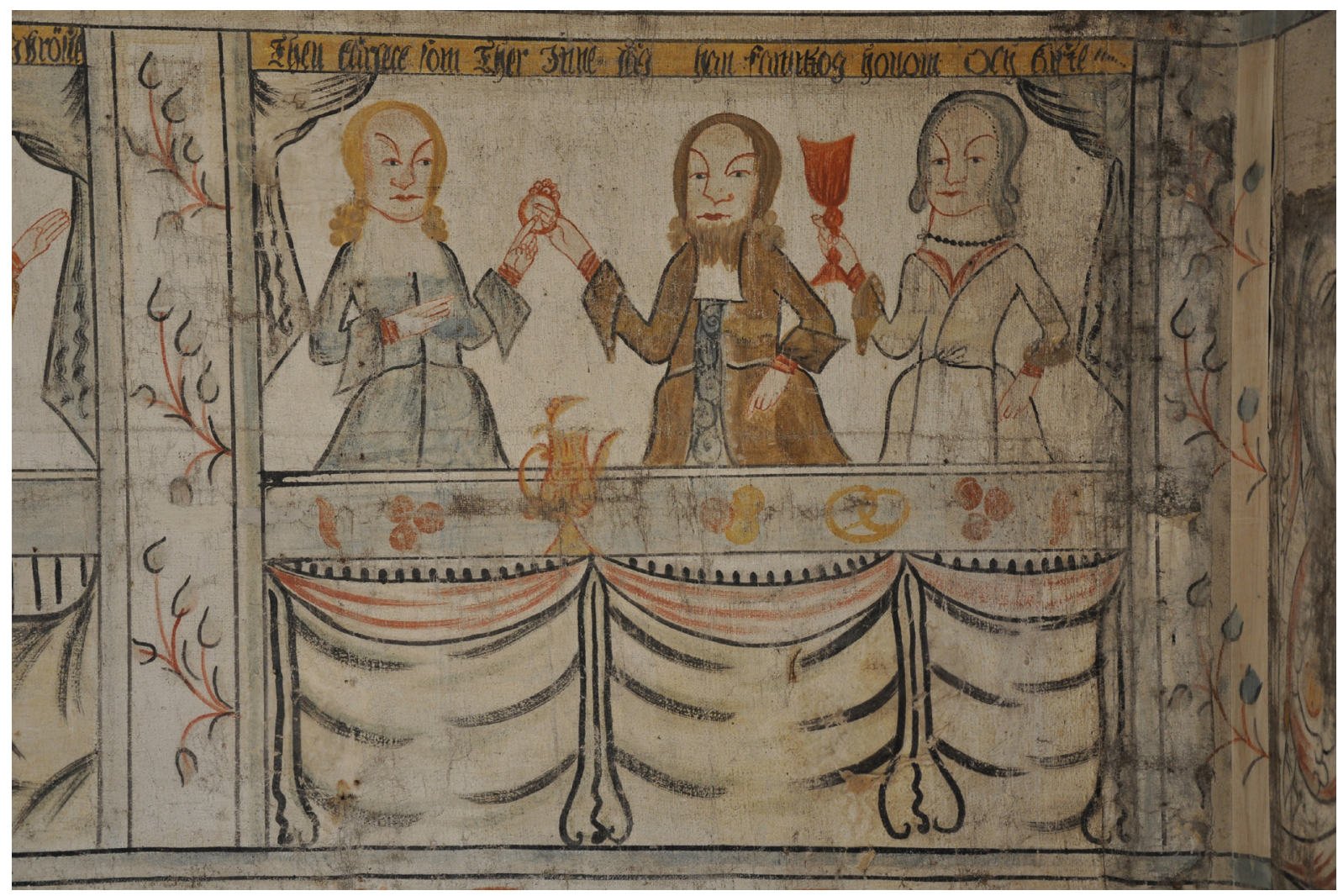

Figur 10 (2.3.10): En målad interiör från 1758, nu i Hälsinglands museum, är ett av de tidigaste kända verk där Erik Ersson, Snickarmålaren, självständigt arbetat med en hel inredning. Han var då 28 år. Foto: Bonny Sjöblom sista kända verk överhuvudtaget, i Eds socken, Ångermanland, daterat 1778. Ett imponerande arbete av en 80-åring. Fem år senare dör han.

Gustaf Reuter må vara den idag mest kända bland utövarna av det så kallade Reutermåleriet. Men han var långt ifrån ensam om sitt manér. Han var inte heller först. En av de mest produktiva bland utövarna inom Reuterskolan var Erik Ersson (eller Eriksson) (1730-1800), i muntlig tradition hågkommen under namnet Snickarmålaren (se fig. 10). Uppgifterna om Snickarmålarens identitet har inte alltid varit entydiga. En uppgiftslämnare till Nordiska museets frågelista "Konstnärlig målning" talade om Snickarmålaren som identisk med en Jonas Eriksson och hänvisar till "Norrbergsstugans målningar [...] utförda år 1774 av bonden Jonas Eriksson i Källeräng". ${ }^{21}$ Där, i dagligstugan (köket) i Norrbergsstugan på Delsbo forngård finns en inskrift från 1913 som presenterar måleriet i stugan som utfört av just Jonas Eriksson "från Källeräng år 1774 gemenligen kallad Snickarmålarn”. Källeräng är en by i Delsbo socken. Uppgiften om Jonas Eriksson som identisk med Snickarmålaren förs sedan vidare av Erixon (Erixon 1937:184), som tolkar signatu-

21. Uppgiftslämnare Lars Munter, Fredriksfors, Delsbo 1930, EU 1478, Nordiska museet. 
ren "EES" som spår efter en tredje målare. Senare har man identifierat Snickarmålaren som Erik Ersson eller Erik Eriksson och knutit denna identitet till signaturen "EE S" (Östlund 1953:58f).

I likhet med Reuter signerade Snickarmålaren sina alster, bland annat måleriet från 1777 i Tjärnmyrastugans kammare, Delsbo forngård. I Norrbergsstugans dagligstuga (kök), på samma forngård, har han signerat ett måleri från 1774 med fyra spegelvända "EE" och två korslagda spegelvända "S" och i likhet med Reuter adderat omegatecknet. En annan av Snickarmålaren signerad interiör är den i Per Nilsas-gården, även den på Delsbo forngård. Den är daterad 1788.

Till de tidigaste av Snickarmålaren signerade interiörerna hör en i Hälsinglands museum bevarad (inv. nr HM 1920). Den kommer från gården Mickels, Nansta by, Forsa socken, och är daterad 1758. Den har ingått i undersökningen. Materialtekniskt utmärker sig Snickarmålaren för användning av indigo, möjligen vejde-indigo. Pigmentet har alltså kommit till bruk både i hans måleri och det med Ovanåkersmåleriet besläktade måleri som påträffats i norra Hälsingland, i det från Per-Ers i Ljusdal från 1735 .

Ett av de sista beläggen för Snickarmålarens verksamhet - han var då 64 år - är ett löst väggfält med hans signatur och dateringen 1794 inom en krans. Den finns i Frisbogården, Bjuråkers forngård, och anses, liksom ett antal bemålade bräder, härröra från Jon Ols i Norrlia (Lundell \& Norberg 1990:131).

Det finns fler inredningar utan signatur men som på stilistiska grunder och genom jämförelser av figurer gjorda efter mall kan attribueras till Snickarmålaren - som exempelvis den i dagligstugan i Jens Ors-gården, Bjuråkers forngård.

Reuters son Carl Roth (1722-1757), också han målare, dog redan vid 36 års ålder och hans verksamhet som målare är följdriktigt betydligt mer begränsad än Reuters och Snickarmålarens. Vi vet att han medverkade vid interiörmåleriet i Högs kyrka 1751 och att han var Snickarmålaren behjälplig vid åtminstone ett tillfälle (Ekelöf 1996:72).

Till Reuterskolan kan man också räkna J. Tillberg (Östlund 1953:62), vars härkomst och familjeförhållanden är väl utredda (Sandberg 2007). Men om hans verksamhet är inte mycket känt. Hittills är bara ett av honom signerat arbete identifierat.

Det har uppenbarligen funnits fler målare som arbetat i samma manér. En signatur "AF" på ett måleri snarlikt Reuters finns i Jens Ors-gårdens herrstuga i Bjuråkers forngård. Måleriet är daterat 1781 
(Lundell \& Norberg 1990:133f). Figurmåleriet är svagt och händerna är oproportionerligt stora. Vem som döljer sig bakom signaturen AF är inte klarlagt. Samma signatur återfinns även på ett annat interiörmåleri påträffat i en gård i Bjuråkers socken och daterat $1783 .{ }^{22}$

Skriftligt källmaterial ger en antydan om alla de målade interiörer som en gång funnits och bekräftar därmed riktigheten i en uppgift från 1930 om de många "tak- och väggmålningar som förr i tiden prydde rummen i bondgårdarna här i Delsbo" men som "nu blivit utplånade". ${ }^{23}$

\section{Reuterskolans ursprung och stildrag}

Att Reuterskolan, i likhet med Ovanåkersmåleriet bygger vidare på ett äldre måleri som funnits i området sedan tidigare är uppenbart och har sedan länge varit känt (Erixon 1923:73). I de efterlämnade interiörerna och möblerna kan olika stildrag identifieras, stildrag som vittnar både om traditionens grepp och om mottagligheten för det nya. Ett väggfält från gården Taggs i Storhaga, Ljusdal, nu i Ljusdalsbygdens museum och daterbart till 1700-talets första decennier, kan ses som en förmedlande länk mellan det äldre och det yngre måleriet (inv. nr LjM 197) (se fig. 11). Samtidigt som motiv och mönster direkt förebådar det fullt utvecklade Reutermåleriet finns i detaljerna anmärkningsvärda likheter med 1500- och 1600-talens måleri i Voxnandalen. ${ }^{24}$ Motsvarande detaljer återfinns i det målade väggfält från gården Kolars, Spångmyra, Bjuråkers socken, som idag pryder kafeterian på Bjuråkers forngård. Även det kan dateras till tidigt 1700-tal. Utanför socknarna i norra Hälsingland har ett snarlikt måleri förekommit. Ett väggfält i Nordiska museets samlingar med proveniens Härjedalen visar samma slags figurer med klädsel i barockens dräktmode. Det är daterat 1724 och attribuerat till målaren Roland Öberg, mest känd för sitt måleri i de norrländska fiskekapellen.

Lagerbladskransen - motivet finns etablerat i områdets måleri redan på en kista med dateringen 1735 (Delsbo forngård) och på bordsskivor från samma tid - är ett renässansmotiv. Så kan även draperimotivet i panelhöjd stilbenämnas. Det förekommer till exempel i Norrbergsstugans

22. Dokumentation av Hilding Mickelsson och Ingemar Svensson 1969, Ljusdalsbygdens museum och Länsmuseet Gävleborg.

23. Uppgiftslämnare Lars Munter, Fredriksfors, Delsbo 1930, EU 1478, Nordiska museet.

24. Tack till Lars Nylander, Hälsinglands museum, för denna observation. 
dagligstuga (kök) och Tjärnmyrastugans kammare, Delsbo forngård. Med rötter i det äldre kyrkliga kalkmåleriet och inom högreståndskulturen har detta motiv sedan tidigare en fast förankring i det norrländska interiörmåleriet som det i Ulvöns fiskekapell från 1719. I norra Hälsingland skulle det leva kvar länge. Även akantuskrokarna är i sin jämna regelbundna upprepning snarare renässans än barock.

Tulpanmotivet (t.ex. Frisbogården, Bjuråker), liksom gardinmotivet, de uppknutna ridåliknande gardinerna (t.ex. Per Nilsas-gårdens herrstuga, Tjärnmyrastugans kammare och Pigloftet, Delsbo forngård; Frisbogården och Jens Ors-gården, Bjuråkers forngård) hör däremot mer hemma i barockens formspråk. Om de målade våderna av draperier $\mathrm{i}$ panelhöjd på väggarna är renässansdrag är de uppbundna ridåliknande gardinerna barock. Samma gardinmotiv möter man också på insidan av locken till kistor av Reuter och Reuterskolans målare. Det är möjligt att Reuters uppdrag att måla "gevantet omkring predikstolen" i Delsbo gamla kyrka 1745 - det beskrivs så i Knut Lenaeus Delsboa Illustrata - gav gardinmotivet en extra skjuts ut i områdets interiör- och möbelmåleri. Men motivet har en äldre hemortsrätt i området. Det förekommer i ett måleri på insidan av locket till en kista från Delsbo, med de två målade dateringarna "1705" (på kistans utsida) och "1706" (på lockets insida) (NM 182001). Dateringarna verkar trovärdiga och autentiska. Kistan är av en typ vanlig i Delsbo från 1600-talets mitt till början av 1700-talet. Dess framsida är försedd med två målade stiliserade vapensköldar av en form som förekommer i områdets möbelmåleri redan på 1500-talet.

Till barockinslagen hör också de ofta återkommande ryttarfigurerna, bibelberättelsens heliga tre konungar i en bildtradition som funnits i

Figur 11 (2.3.11): Målat väggfält från 1700-talets förra hälft. Här finns länkar både framåt och bakåt i tiden. Krönet på den stiliserade pilastern är av en form som förekommer i 1600-talets hälsingemåleri (LjM 197). Foto: Yngve Söderquist 
landskapet sedan tidigare. De utgör huvudmotiv i väggfältet från Taggs i Ljusdal från tidigt 1700-tal, hade enligt Olof Broman varit vanliga $\mathrm{i}$ området sedan tidigare, och upprepas därefter gång på gång i de målade interiörerna av Reuter, Snickarmålaren och andra företrädare för Reuterskolan. Det äldsta daterade väggfältet med detta motiv som signerats av Reuter är det ovan nämnda från 1740, nu i Hälsinglands museum. De är utförda efter förebild från samtida och något äldre gravyrer. Deras ikonografiska innehåll, tolkningen av dem i deras samtid och den stilistiska utformningen, variationen och förenklingen hos dem i förhållande till förlagorna har noga utretts (Nodermann 1984).

Diagonalrutorna eller spaljémotivet i rokoko kan konstateras så tidigt som på ett gavelstycke från gården Dobblars, Frisbo, Bjuråker, daterat 1766 (kafeterian, Bjuråkers forngård). Det hör till en svit som signerats "Gustaf Reuter" (Lundell \& Norberg 1990:130) och som dessutom försetts med omegatecknet och stjärnor inom en lagerbladskrans, detaljer som stärker, om än inte bekräftar, signaturen. Måleriet är ett anmärkningsvärt tidigt exempel på rokokoelement i allmogesammanhang, där rokokon mer allmänt annars börjar sätta avtryck först under 1780 -talet.

\section{Personliga handlag och manér - attribuering}

utifrån frihandsmåleri och verktygsspår

Trots stora likheter överlag har det i interiörmåleriet gått att identifiera olika målares handlag och särskiljande detaljer. De av Reuter och Snickarmålaren signerade och bevarade interiörerna är tillräckligt många för att tillåta en något så när trovärdig analys av handlag och favoriserade detaljer. Det är framför allt i de på fri hand utförda detaljerna som det personliga handlaget - och därmed de iakttagelser som är mest avgörande för attribueringen - visar sig. Mallar, schabloner och stämplar kan vara ett indicium men som attribueringskälla inte fullt tillförlitliga då de olika målarna kan ha samverkat och lånat verktyg av varandra. Användningen av mallar för ryttarfigurerna och hästarna i det ofta återkommande motivet trekonungaritten har tidigare framförts som en hypotes av Maj Nodermann (opublicerat manus).

Genom kalkering och jämförelser har det gått att påvisa användningen av mallar för återkommande detaljer som till exempel ett visst sätt att framställa händer. Kalkering kan fungera som ett stärkande indicium i våra försök att identifiera osignerade verk, exempelvis måleriet i Jens Ors-gårdens dagligstuga (Bjuråkers forngård) som ett verk av 


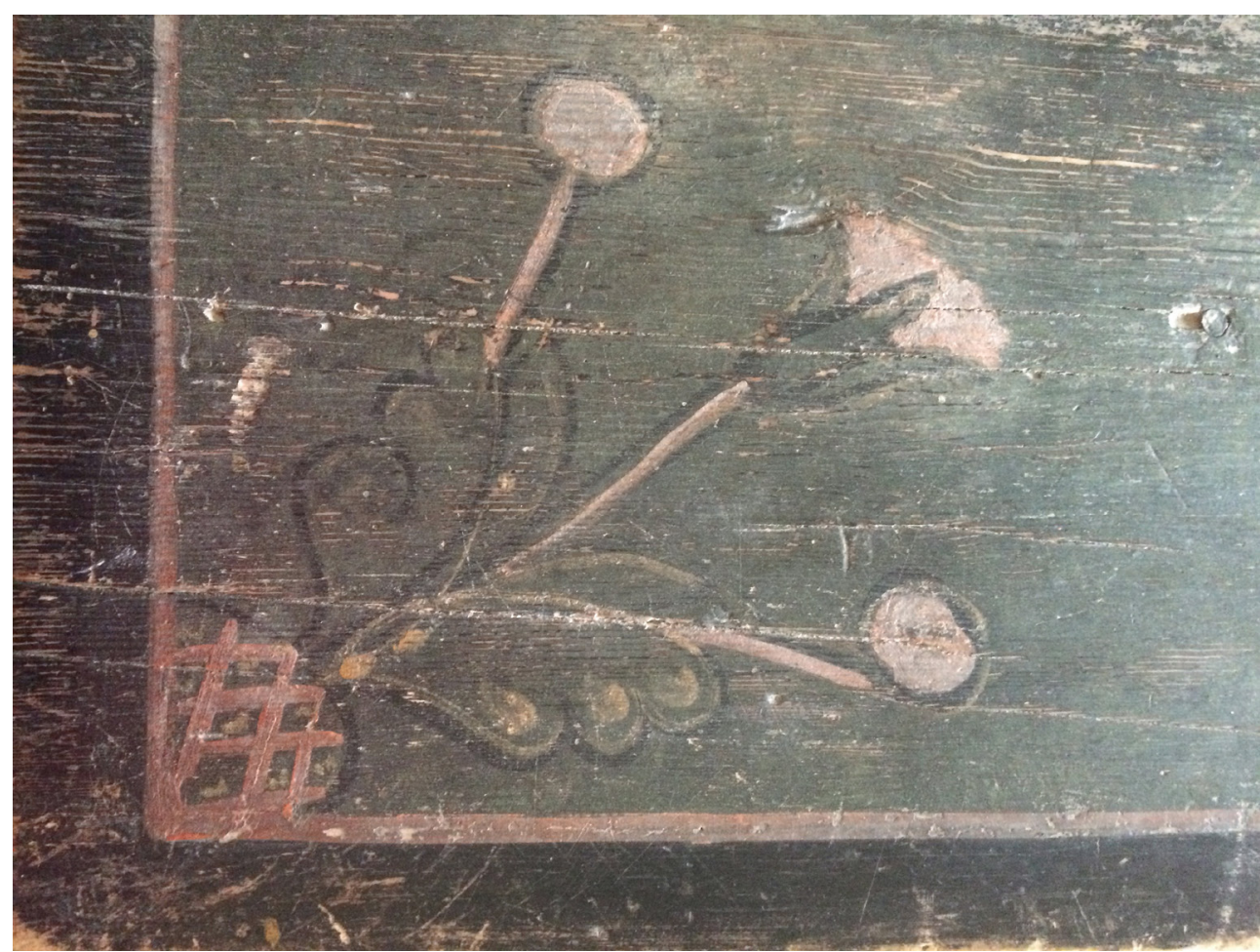

Snickarmålaren. 1747 års väggmåleri i Delsbogården på Skansen, som fram tills nu ansetts vara i sin helhet utfört av Reuter, rymmer bilder av händer enligt samma mall.

Erixon observerade det för Snickarmålaren personliga målningssättet, med säreget "stiliserade typer och former" (Erixon 1937:181f), avvikande från Reuters manér. Det är något som senare även Östlund kommenterar (Östlund 1953:58ff). En karaktäristisk detalj är linjen som markerar käkbenets nedre kant i figurernas ansikten.

Detaljer i återgivningen av hästarna ger ytterligare exempel på de olika målarnas personliga manér. Medan Reuter företrädesvis målar hästhuvudena kantiga och med raka betsel gör Snickarmålaren dem mjukt rundade med betsel som följer den rundade formen. Målaren med signaturen "AF" (Jens Ors-gården, Bjuråkers forngård) avbildar hästhuvuden utan lång pannlugg på ett sätt som avviker från såväl Reuter som Snickarmålaren. Den yttersta fliken av akantusrankorna är i Reuters versioner fyllda med prickar vilket inte tycks förekomma i Snickarmålarens fall.

Möbelmåleri i Reuterskolans stil - bord, kistor och skåp

I Delsbo och Bjuråker finns anmärkningsvärt mycket signerat interiörmåleri från 1700-talet bevarat. När det gäller möbler är det sämre ställt
Figur 12 (2.3.12): Bordsskiva med måleri i form av bloomsterbuketter i hörnen. Delsbo forngård. Foto: Johan Knutsson 
med signaturer. Det finns ett flertal möbler vars måleri visar de för Reuter eller Reuterskolan typiska dragen - men inte något uttryckligen signerat.

Mest handlar det om kistor men också om de i Delsbo så vanliga långborden. Åtskilliga långbordsskivor med ståtligt måleri och målade dateringar har bevarats till idag. I bouppteckningarna upptas både "långbord" och "målade långbord". Liksom vändbänken har de en gammal tradition i området. Det finns många exempel på långbordsskivor med dateringar från 1600-talet men också enstaka bordsskivor från seklet dessförinnan, varav en med dateringen 1575 (Östlund 1953:44) och en daterad 1590, i Nordiska museets samlingar (Erixon 1923:83).

Bland långbordsskivorna från 1700-talet har ett exemplar i Delsbogården på Skansen utpekats som ett möjligt arbete av Reuter (Strömberg 1941:158). I dess måleri ingår både de för Reuter typiska änglabelätena och bårdslingorna.

Det finns även en långbordsskiva i Frisbogården i Bjuråkers forngård med de för Reuter typiska stjärnorna och omegatecknet. Ytterligare en bordsskiva, attribuerad till Reuter och daterad 1746, finns i Norrbergsstugan, Delsbo forngård. Den sistnämnda har ett måleri i svart, mörkgrönt, blymönjerött och en brun trasådring. Inom kransen återfinns den för Reuter typiska kalligrafiska slingan och stjärnorna. Analyserna av dem har varit enbart okulära.

De tidigaste exemplen på den typiska Delsbokistan med dess nedåt och inåt sluttande sidor är de kistor som försetts med målad dekor i Reuters stil. Typen har tidigare särskilt uppmärksammats med två exempel från 1771 och 1778. Den förstnämnda finns i Hälsinglands museum (HM 1716). Den andra, i privat ägo, har ett måleri som in i minsta detalj motsvaras av måleriet på en kista i Bjuråkers forngård, vilken dock är av en annan form, större och med lodräta sidor. Den sistnämnda är försedd med den målade dateringen 1779 i den vänstra av framsidans två vapensköldar. Ett snarlikt måleri, fast då bara på insidan av locket, återfinns också på en annan mindre kista i samma hembygdsgårds samlingar. Den bär dateringen 1778 .

Ytterligare några kistor med den för Delsbo specifika formen med nedåt och inåt sluttande sidor är intressanta i sammanhanget. En av dem, i Söderhamns museum (SM 1864), är med sin målade datering 1759 i en av framsidans två målade vapensköldar den av mig hittills äldsta kända kistan av denna form. Såväl de dekorativa vertikala bårderna längs hörnen på kistans utsida som draperimotivet, änglafigu- 


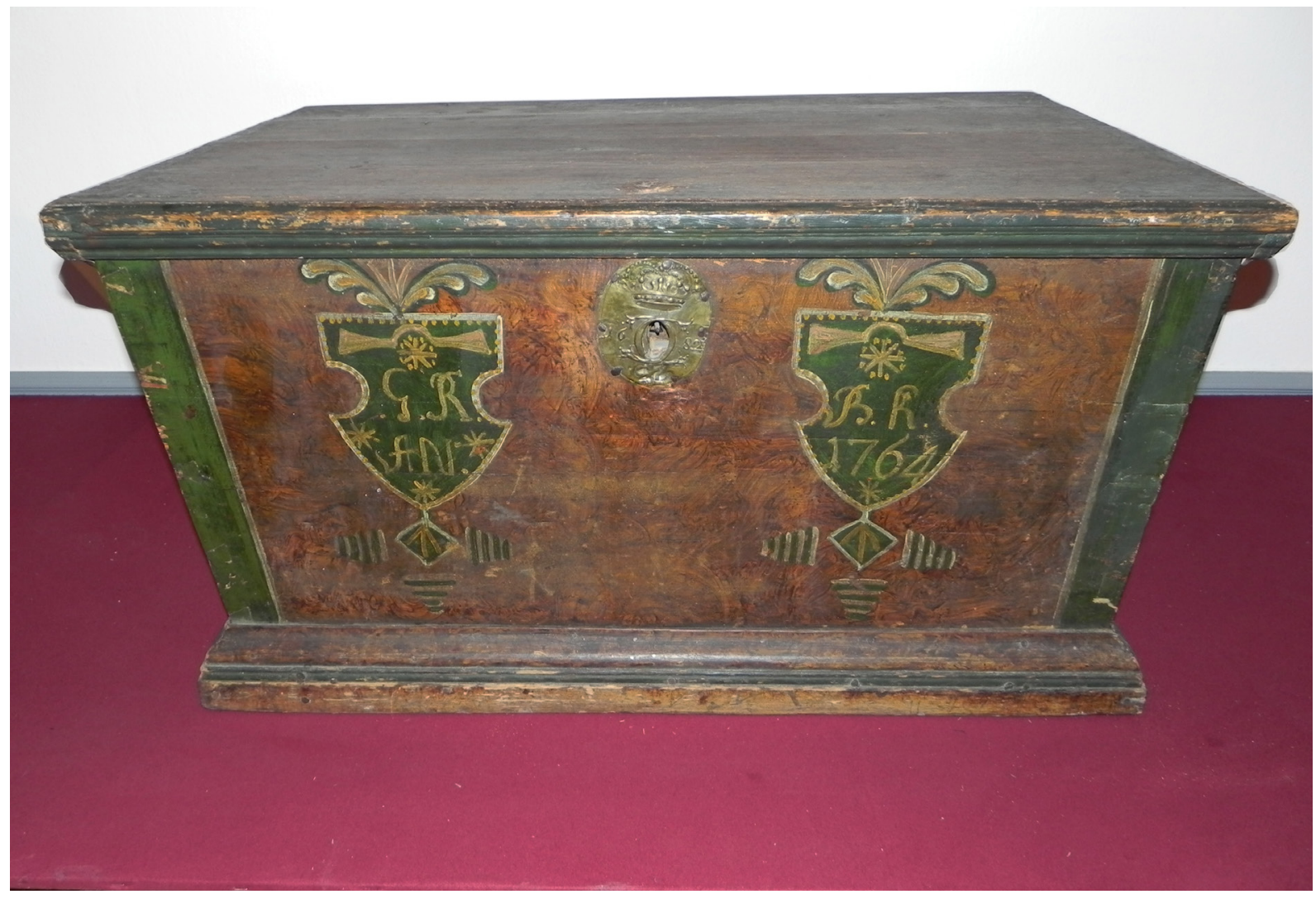

rerna, äpplena och stjärnorna på lockets insida pekar på Reuter som upphovsman.

En annan kista i Hälsinglands museum, med inåt och nedåt sluttande sidor, är försedd med årtalet 1764 (HM 9037). Den kan med stor sannolikhet tillskrivas Reuter (se fig. 13). Framsidan är försedd med initialerna GR, för Gustaf Reuter, respektive B K, för hustrun Brita Klingström - vilket torde vara tillräckligt för att säkerställa attribueringen och proveniensen. Måleriet på utsidan har identifierats som oljefärg respektive en hartsbaserad drickamålning. Ockra, blyvitt och spanskgrönt ingår bland pigmenten.

Bland skåpen är det särskilt ett i Ljusdalsbygdens museum, daterat 1774, som förtjänar uppmärksamhet (LjM 9431) (se fig. 14). Det består egentligen av två skåp där det ena ställts ovanpå det andra. Vid första anblicken verkar de höra ihop men vid närmare granskning visar det sig att de profilhyvlade listerna på överskåpet skiljer sig så mycket från motsvarande lister på underskåpet att de två delarna knappast kan vara gjorda i samma verkstad - åtminstone inte vid samma tillfälle. Skåpet, som 1971 ställdes ut på länsmuseet i Gävle och förvärvades av Ljus- 
Figur 14 (2.3.14):

Detta skåps måleri, daterat 1774, har med all sannolikhet utförts av Gustaf Reuter (LjM 9431). Foto: Yngve Söderquist

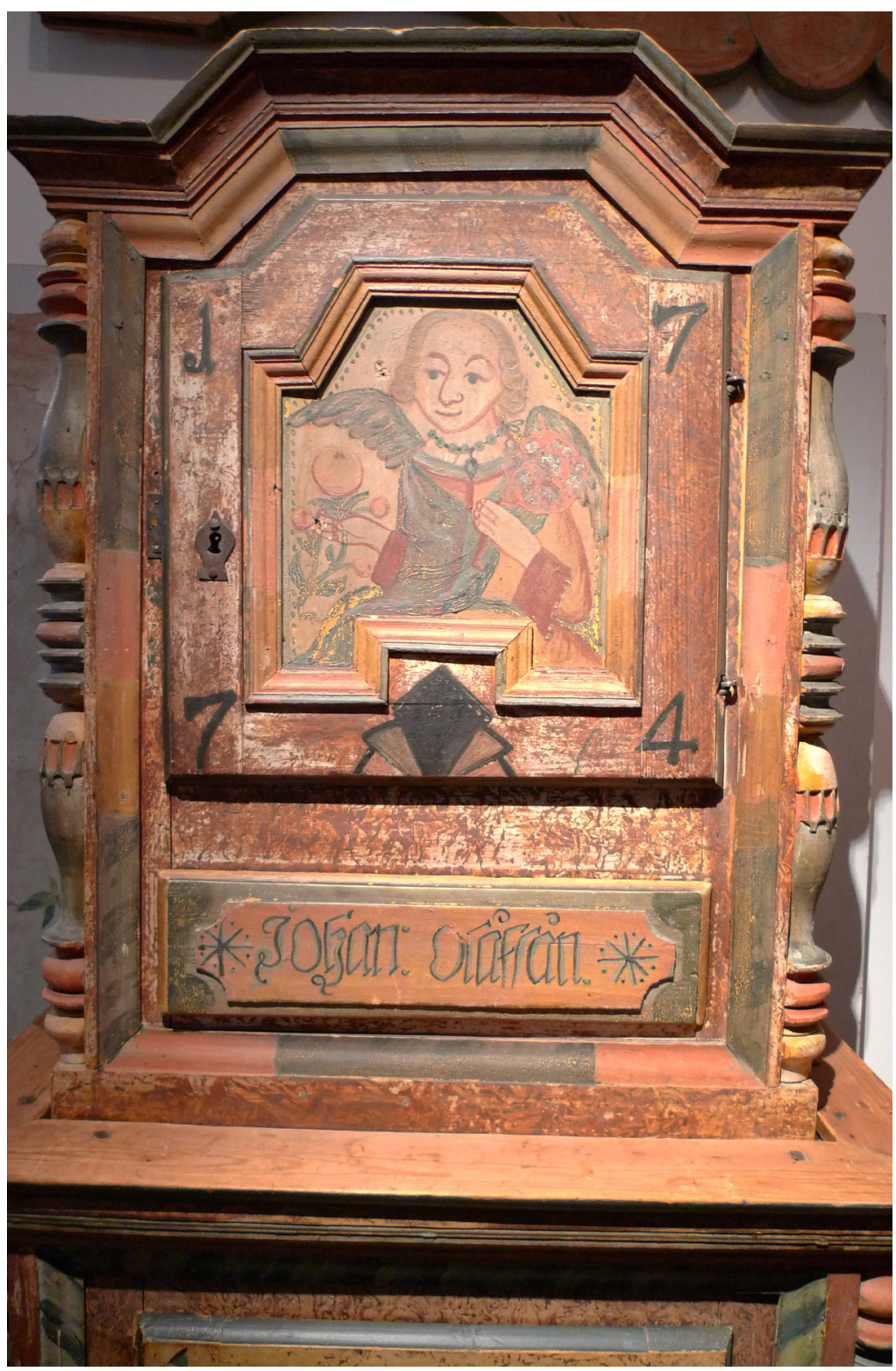

dalsbygdens museum 1999, har sedan länge i sin helhet ansetts vara målat av Reuter. En konnässörskapsanalys styrker en sådan förmodan - åtminstone vad överskåpet beträffar. Lister och dekorativa balusterdockor är målade med en oljebaserad färg medan de större ytornas färg identifierats som ett drickamåleri - allt utfört på en vit grundering (se vidare kapitel 3.5 Konstteknologiska undersökningar av hälsingemåleri). 


\section{Måleriet i Voxnandalen, Dellenbygden och Dalarna - en jämförelse}

Medan måleriet i Dellenbygden representeras av ett stort antal mer eller mindre välbevarade interiörer - där även takmåleriet har bevarats - har det motsvarande 1700-talsmåleriet i Voxnandalen med få undantag som inredningen i Ol-Mårs i Alfta enbart blivit kvar i form av lösa delar och fragment. En annan skillnad är att måleriet i norr i så hög grad är signerat medan det i söder i stort sett är osignerat. Vilka andra skillnader - och likheter - kan iakttas? Hur kan de beskrivas, sammanfattas och tolkas? Och vad kan jämförelsen mellan det hälsingska måleriet och det närbesläktade måleriet i Svärdsjö och Enviken ha att berätta om nätverk, om förbindelser mellan olika områden, om arbetsformer, samverkan och konkurrens, om identitetsbygge och om estetiska ideal?

\section{Likheter och olikheter i färg och form}

De flesta av Gustaf Reuters stora inredningsuppdrag i Delsbo och Bjuråkers socknar är från åren kring 1750 och senare. Hypotetiskt skulle Reuter ha kunnat ta intryck av Ovanåkersskolans måleri som fanns färdigutvecklat i södra Hälsingland redan före 1700-talets mitt (Erixon 1937:187; Knutsson 2007a:34). Förekomsten av väggfältet från Per-Ers i Hamre, Ljusdal, med dateringen 1735 skulle kunna tyda på att åtminstone någon av målarna från Voxnandalen tagit sig från södra delen av landskapet till norra i jakten på arbete ungefär vid den tid då Reuter etablerar sig som målare i norra Hälsingland.

Vissa inslag i Reuters repertoar, som de stiliserade blomsterurnorna med deras om grankottfjäll eller påfågelsfjädrar erinrande kompositioner, är i detalj så till den grad överensstämmande med dem i Ovanåkersmåleriet att ett samband måste förutsättas (Knutsson 2007b:91). Detaljer och motiv som förenar de båda områdenas måleri med varandra är också renässansens lagerbladskransar och barockens stiliserade tulpaner.

Vad olikheterna beträffar skiljer sig 1700-talets Ovanåkersmåleri från Reuterskolans måleri och det senare dalmåleriet främst genom att figurer, landskap eller byggnadsmotiv - förutom kolonnställningen aldrig förekommer i Ovanåkersmåleriet. Kolonner omvirade med vinrankor ingår i det av Erik Ersson, Snickarmålaren, signerade måleriet från 1777 i Tjärnmyrastugans kammare, Delsbo forngård liksom i måleriet från $1766 \mathrm{i}$ kafeterian, Bjuråkers forngård och på ett löst väggfält 
i Frisbogården, samma forngård. Annars är detta något för Ovanåkersmåleriet specifikt. Barockens uppbundna inramande ridågardiner är ett för norra Hälsinglands målare säreget och långlivat motiv - uppenbarligen har det varit gångbart i hundra år - som inte förekommer i södra delen av landskapet.

Det har varit de i närområdet lätt åtkomliga pigmenten som dominerat i både Voxnandalens och Dellenbygdens måleri. Färgskalan i Delsbos och Bjuråkers interiörmåleri är i stort sett densamma som hos Ovanåkersmåleriet. Den blå färgen i det med "AF" signerade måleriet från 1781 i Jens Ors-gården (Bjuråkers forngård) och det ännu oidentifierade måleriet i Norrbergsstugans herrstuga och förstuga (Delsbo forngård) påminner om den blå färgen hos interiören från gården PerErs i Ljusdalstrakten. Några färgpigment har påvisats och identifierats. Enligt en muntlig tradition har det gulockra färginslaget i Reuters måleri ansetts komma från Avholmsberget och Säljesta by i Järvsö.

\section{Modenytt och stadspåverkat - tradition och egenart}

De vinranksomlindade kolonnerna är ett motiv som under loppet av 1700-talet kom att etableras med särskild styrka i just Voxnandalen. I Ovanåker går Eric Jonsson i sin fars fotspår med just de ingredienserna. Gång på gång återkom de till de vinranksomlindade kolonnerna - om än i kombination med rokokoelement och ett moderiktigt uppdaterat formspråk (Olanders 1996:87f). Ännu vid 1800-talets mitt förekommer schablonmålade vindruvsklasar mot en i övrigt på fri hand målad yta i världsarvsgårdarna Jon Lars och Pallars, där en dalmålare från Rättvik anpassat sitt måleri efter det på orten gångbara.

Om vi föreställer oss att det finns ett samband mellan ekonomiskt välstånd och målade interiörer indikerar antalet sådana i Voxnandalen och Dellenbygden att båda områdena bör ha upplevt ett ekonomiskt uppsving med början vid 1700-talets mitt. På Mårtesgården i Edsbyn finns ett interiörmåleri av Rättviksmålaren Björ Anders Hansson signerat och daterat 1811. På baksidan finns ett äldre måleri i Ovanåkersstil bevarat. Femtio år efter att detta tillkommit har man alltså ansett det vara dags för en förnyelse med återanvändande av samma duks baksida för ett mer moderiktigt måleri. Likaså har man för måleriet i gården Per-Ers i Ljusdal återanvänt duken med ett måleri från 1735 för ett nytt måleri på dukens baksida hundra år senare. I Delsbo och Bjuråkers socknar är detta svårare att finna exempel på. Kanske har man i Dellenbygden vårdat det traditionella med större kraft medan man i Voxnandalen 
varit mer benägen att förse sina hus med ett mer moderiktigt måleri? Det är i så fall en hypotes som stämmer med en uppfattning att intresset för att bibehålla det gamla traditionella varit särskilt utvecklat i Delsbo och Bjuråker (Andersson 2005). Eller är det så att vi här helt enkelt ser resultatet av olika ekonomiska förutsättningar? Nybyggnationen har under 1800-talet varit särskilt omfattande i Voxnandalen med tillkomsten av stora trevåningshus i herrgårdsstil.

Förnyelsen, alternativt bibehållandet, av de målade interiörerna kan i och för sig förklaras med en stark, alternativt svag ekonomi. Å andra sidan är det inte nödvändigt att alltid se det lokala måleriets blomstring som uttryck för ett materiellt välstånd. När det gällde de i bygden bosatta målarna, till exempel Reuterskolans utövare, har det visat sig att dessa ofta ersattes för sina insatser genom dagsverken, hjälp med timring, vägbyggen eller leverans av olika varor som hö eller näver (Ekelöf 1996:66ff).

Benägenheten att anamma ett nytt formspråk kan ses som uttryck för ett intresse för nyheter. Det kan också ses som ett uttryck för välstånd. Men på båda dessa punkter finns alltså, som vi sett, olika möjligheter till tolkningar som inte nödvändigtvis kopplar samma stilistiska förnyelse med ekonomi.

Ett mer entydigt sätt att mäta områdets välstånd och intresset för nyheter är användningen av material. Medan arbetskraften kunde betalas med gentjänster eller in natura var tillgången på olika material avhängigt både kontanter och intresse för nyheter.

Att de olika stilarna slår igenom med olika kraft i de olika delarna av landskapet vid olika tidpunkter är något som redan Manne Östlund framhöll (Östlund 1953:45). Maj-Britt Andersson har sedan ur ett konst- och kulturvetenskapligt brett perspektiv analyserat denna stilhistoriska anakronism och de olika orternas olika stilpreferenser (Andersson 2000:171ff; Andersson 2005). Hon framhåller de för oss idag dolda budskap som fanns inbyggda i måleriets motiv, mönster, stil och karaktär och återkommer i sin forskning ofta till det faktum att målarna bara anammade de nyheter "som passade traditionen, socknen och det redan givna" (Andersson 2010:40). Att något förefaller retarderat behöver varken bero på ekonomisk tillbakagång eller bristande förmåga att följa med i stilutvecklingen. En bakomliggande orsak kan enligt Andersson istället vara en medveten strategi och vilja att välja en stil som man känt som socknens egen. 
Figur 15 (2.3.15): Målad interiör i Svärdsjö gammelgård, signerad Hans Ersson Enman. Foto: Johan Knutsson

\section{Förebild för dalmåleriet?}

Ovanåkersmåleriet har ett tydligt samband med det möbel- och inredningsmåleri som Hans Ersson Enman (1727-1773) i Svärdjö och Envikens socknar utvecklade på 1750- och 1760-talen (Engström 1995), en omständighet som tidigt noterades (Erixon 1937:188; Östlund 1953:63f). I Svärdsjö och Enviken finns flera interiörer signerade av Enman. De är daterade 1759, 1760 och 1766 . Ett motsvarande arbete av samme målare, monterat som delar av en interiör med måleri på hyvlade takbrädor och grov väv finns i Dalarnas museum, Falun. På en takbjälke finns den målade dateringen "1760". Gustaf Ankarcrona besökte gården "Espes" i Edsbyn med dess målningar som han tillskrev Hans Ersson Enman. Attribueringen är förståelig men vid ett närmare studium av detaljer i handlaget förefaller den ändå osannolik. Det är för mycket som skiljer det från de av Enman signerade arbetena.

Erixon ansåg det som "fastslaget, att det var Enman, som inspirerades från Hälsingland och icke tvärtom" (Erixon 1937:188). Och senare forskare har stämt in (Jacobsson 1983:112). Ett indicium för det är den spridning som denna typ av måleri

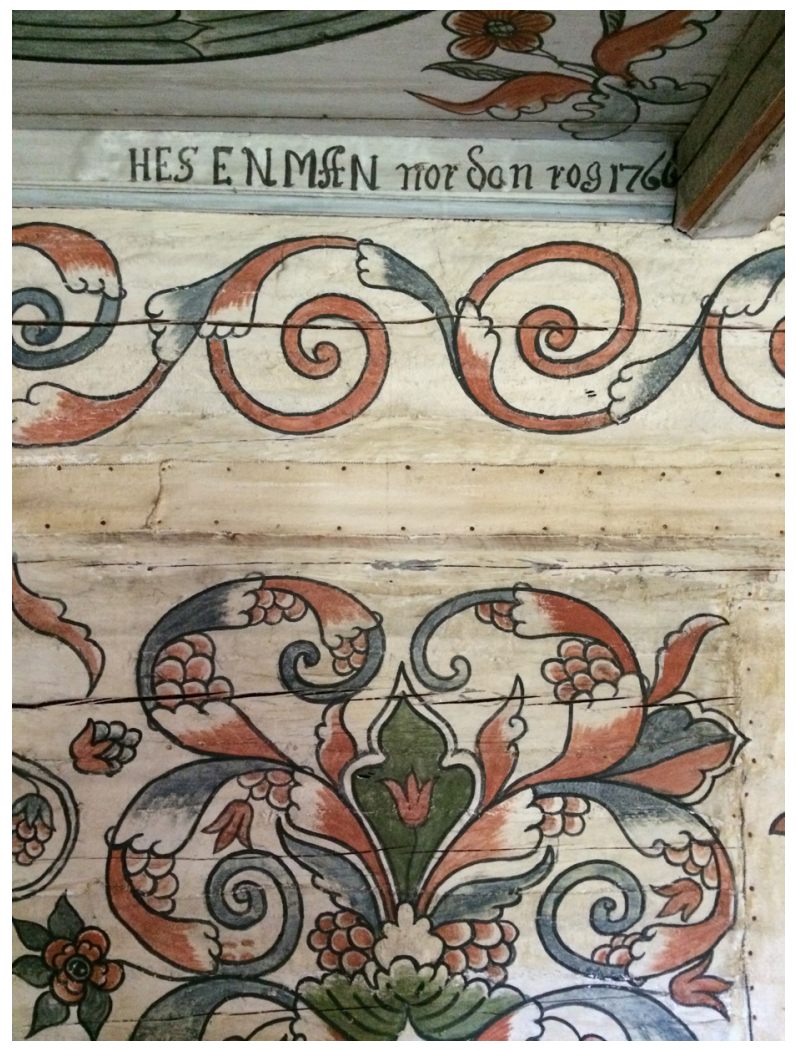
hade i Hälsingland medan motsvarande måleri i Dalarna tycks ha varit mer begränsat, både geografiskt och kronologiskt: lokalt begränsat i geografin, och dessutom något senare. Enmans äldsta kända interiör är den från 1759. Två kistor i Nordiska museets samlingar går att attribuera till honom. Och de är något äldre. Den ena bär en målad datering "1755" tillsammans med namnen "Annbritan Anders Dotter" och "Jan HanSon" samt bokstavskombinationen "HES" som sannolikt står för Hans Ersson Enman (NM 183307). Den andra kistan är daterad 1758 (NM 160717). Ytterligare en kista med omisskännligt Enmanmåleri finns i Dalarnas museum (DM 11115). Den saknar både signering och datering men borde ha tillkommit omkring 1760. 


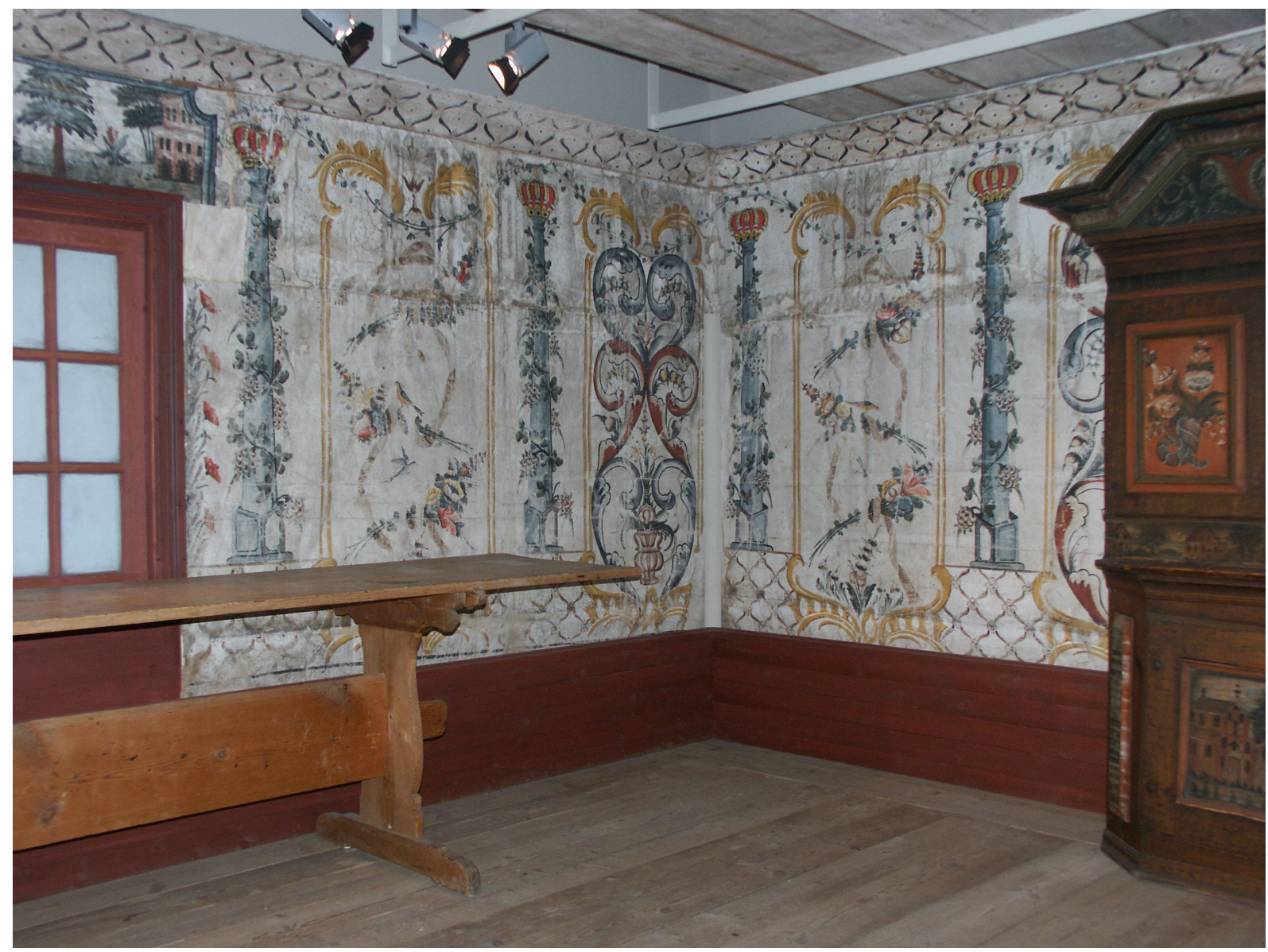

Liknande symmetriskt arrangerade akantuskrokar förekommer även i det senare dalmåleriet, som i en interiör i bröllopsstugan från Hjulbäck i Siljansnäs socken (återskapad i Leksands kulturhus), troligen utförd av Elias Eliasson - namnet "Elias" skrivet i ett hörn av ett av väggfälten har tolkats som en signatur för honom - och daterad 1782 (Knutsson 2007b:94). I Hjulbäcksinteriören ingår kolonner omlindade med vinrankor vilket stärker sambandet med Voxnandalen. Figurscenerna och särskilt kurbitsblomstren är däremot specifika för dalmåleriet.

Mellan Ovanåkers och Alfta socknar i norr och Svärdsjö och Envikens socknar i söder har utbytet av varor och tjänster varit stort. När nya bänkar skulle tillverkas för Alfta kyrka 1681 gick uppdraget till "Snickaren Mr Hans Oluffsson ifrån Swerdsio". Samme snickare fick också samma kyrkas uppdrag att tillverka en ny predikstol med tillhörande himmel.

Även kontakterna mellan Siljansbygden och Voxnandalen var täta och Ovanåkersmåleriet kan troligen utpekas som en av utgångspunkterna för det motiv som under 1770- och 1780-talen skulle utvecklas 
till Dalarnas kurbits. Redan Sigurd Erixon noterar hur dessa "eleganta, påfågelsmässigt utbredda jättekottar med insprängda blommor [...] på ett intressant sätt förebildar Rättviksmålarnas stiliserade blomkaskader" (Erixon 1937:188). Ännu hade inte "kurbits" slagit igenom som benämning när Erixon gjorde sina observationer. I Nordiska museets katalogkortstexter från 1930-talet anges motiven hos dalmåleriets föremål som "dalkarlsblommor" eller "rosmåleri".

Likheterna mellan Voxnandalens måleri och Siljansbygdens kurbitsmåleri är onekligen slående. Att närmare utreda i vilken mån och på vilket sätt det senare inspirerats av det förra vore en angelägen uppgift. Hjulbäcksinteriören från 1782 är en intressant förbindelselänk i det sammanhanget. Var Ovanåkersmåleriet i själva verket en av de viktigaste utgångspunkterna inte bara för Enmans måleri i Svärdsjö och Enviken utan också för utvecklingen av Siljansbygdens kurbitsmåleri?

Även förhållandet mellan Reuterskolans måleri, Hans Ersson Enmans och den senare Leksandsmålaren Jufwas Anders Erssons måleri är intressant att närmare analysera (Knutsson 2007b:94). Tills vidare får det räcka med att konstatera de slående likheterna i form av takrundlar av i stort sett samma utseende i såväl Reuterskolans måleri som i Jufwas Anders Erssons inredningsmåleri i Nises källarstuga, Djura hembygdsgård. Och vilken roll spelade Dellenbygdens måleri med dess kurbitsliknande blomstermåleri som Reuter tillsammans med sonen Carl försåg läktaren i Högs kyrka 1751-1752 med?

Mycket återstår att utreda beträffande förhållandet mellan Hälsingland och Dalarna och hur utbytet av konstnärliga impulser skett. Kanske man ändå kan våga förmoda att medan 1800-talets inredningsmåleri i Hälsingland domineras av målare från Siljansbygden var 1700-talet en tid då inredningsmåleriet $\mathrm{i}$ landskapet utvecklades av målare bosatta och verksamma inom landskapets gränser. Och att Hälsingland i förhållande till omgivande landskap, och ifråga om utvecklingen av det folkliga inredningsmåleriet, då varit den givande parten, mer än den mottagande. 


\section{Referenser}

Arkiv: Nordiska museet, Etnologiska undersökningar, EU.

Kapitlet bygger till största delen på föremålsstudier i Nordiska museet, Hälsinglands museum, Ljusdalsbygdens museum, Dalarnas museum, Söderhamns museum, Edsbyns museum, Delsbo och Bjuråkers forngårdar samt Svärdsjö gammelgård.

\section{Tryckta källor}

Andersson, Maj-Britt (2000). Allmogemålaren Anders Ädel. Diss. Uppsala: Uppsala universitet.

Andersson, Maj-Britt (2010). Sköna hem i Hälsingland. Byggnadskultur 2010:4.

Andersson, Maj-Britt (2005). Hudiksvalls rokoko eller Delsbos barock? Stilpreferenser i en hälsingesocken på 1700-talet. Fataburen: kulturhistorisk tidskrift. Stockholm: Nordiska museet.

Aronsson, Yngve (2014). Vem var Måns Snickare i Hudiksvall? Hälsingerunor 2014 . Bedoire, Fredric \& Lis Hogdal (2000). Den stora hälsingegården: gårdar och befolkning $i$ Voxnans dalgång.

Bondjers, Rune (2007). Det började med möbelmåleri efter en kunglig "upmuntran”. I: Dalmåleri: dalmålarna - deras liv och verk. Dalarnas fornminnes- och hembygdsförbunds skrifter $n r$ 38. Falun: Dalarnas museum i samarbete med Nordiska museet.

Bringéus, Nils-Arvid (1985). En brudkista från Delsbo. Hälsingerunor 1985 .

Decorated Farmhouses of Hälsingland: Swedish World Heritage Nomination 2011, 2011.

Ekelöf, Kjell (1996). Måleri i Delsbo och Arbrå 1749-50. Hälsingerunor 1996.

Engström, B. (1995). Hans Ersson Enman. Envikens hembygd-kontaktblad för medlemmarna $i$ hembygdsföreningen 1995:2.

Erixon, Sigurd (1923). Hälsingarnas hem. Svenska Turistföreningens årsskrift 1923. Stockholm: Wahlström \& Widstrand.

Erixon, Sigurd (1929). Nummer tio Växbo: en bondgård av hälsingesnitt. I: Wallin, Sigurd \& Sigurd Erixon (red.). Svenska kulturbilder, bd I. Stockholm: Skoglunds bokförlag.

Erixon, Sigurd (1937). Hälsinglands bygdemåleri. I: Wallin, Sigurd \& Sigurd Erixon (red.). Svenska kulturbilder, ny följd, bd IV. Stockholm: Skoglunds bokförlag.

Fors, Yvonne \& Sven Isaksson (2018). GCMS Analyses by Direct Methylation (Permetylation) of Lipids in Binders Used in $18^{\text {th }}-19^{\text {th }}$ Century Folk Painted Interiors in Hälsingland, Sweden. Journal of Archaeological Science: Reports, 23, s. $127-136$.

Gustafsson, Gotthard (1941). Delsbogården. Fataburen: kulturhistorisk tidskrift. Stockholm: Nordiska museet.

Hamberg, Per-Gustaf (1974). Norrländska kyrkoinredningar: frän reformationen till ortodoxi (Kungl. Vitterhets Historie och antikvitets akademien), Stockholm: Almqvist \& Wiksell.

Hillgren, Bror (1982). En ålderdomlig kistdekoration. Fataburen: kulturhistorisk tidskrift. Stockholm: Nordiska museet.

Jacobsson, Bengt (1983). Svensk folkkonst, del I. Lund: Bokförlaget Signum. 
Knutsson, Johan (2007a). Dalmåleri i jämförande perspektiv. I: Dalmåleri: dalmålarna-deras liv och verk. Dalarnas fornminnes- och hembygdsförbunds skrifter nr 38. Falun: Dalarnas museum i samarbete med Nordiska museet.

Knutsson, Johan (2007b). Dalmåleriet i konst- och inredningshistorien. I:Dalmåleri: dalmålarna - deras liv och verk. Dalarnas fornminnes- och hembygdsförbunds skrifter nr 38. Falun: Dalarnas museum i samarbete med Nordiska museet.

Knutsson, Johan (2014). Delsbokistan och möbelmåleriet i norra Hälsingland under 200 år. Hälsingerunor 2014.

Lundell, Jan \& Åke Norberg (1990). Svågadalen. Hudiksvall: Hälsinglands museum.

Nodermann, Maj (1965). De nyfunna bonaderna i Alfta. Fataburen: kulturhistorisk tidskrift. Stockholm: Nordiska museet.

Nodermann, Maj (1984). Från Altranstädt till Delsbo: bildtryck och bonader med Carl XII. Stockholm: Nordiska museet.

Nodermann, Maj (1997). Bonadsmåleri $i$ Norden från medeltid till Vasatid. Nordiska museets Handlingar 125. Stickholm: Nordiska museets förlag.

Nodermann, Maj (1998). Gustaf Reuter. Svenskt biografiskt lexikon.

Nylander, Lars (2003). Allmogemålaren Eric Ericsson och inredningsmåleriet i södra Hälsingland vid 1800-talets mitt. Hälsingerunor 2003.

Nyström, Ingalill (2012). Bonadsmåleri under lupp: spektroskopiska analyser av färg och teknik i sydsvenska bonadsmålningar 1700-1870. Diss. Göteborg: Göteborgs universitet, Tillgänglig på: http://hdl.handle.net/2077/30154

Olanders, Gustaf (1996). Tre generationer Ovanåkersmålare. Hälsingerunor 1996.

Sandberg, Elvi (2005). Målaren Gustaf Reuters föräldrar och familj. Hälsingerunor 2005 .

Sandberg, Elvi (2007). Jakob Marcusson Tillberg: en 1700-talsmålare i Bergsjö. Hälsingerunor 2007.

Sinha, Kerstin \& Gärd Folkesdotter (2002). Bild på bondevägg: hälsingegårdarnas måleri. Hudiksvall: Hälsinglands museum.

Strömberg, Elisabeth (1941). Möbleringen av Delsbogården. Fataburen: kulturhistorisk tidskrift. Stockholm: Nordiska museet.

Svensson, Ingemar (1969). Gustaf Reuter, soldat och bygdemålare. Bocken. Arsskrift för Hälsinge regementes Kamratförening 1968/69. Gävle: Hälsinge regementes kamratförening.

Wahlund, Sten (red.) (1945). Sveriges släktregister: Ovanåkers socken. Stockholm: Sveriges släktregister.

Östlund, Manne (1953). Dekorativt inredningsmåleri i Hälsinglands bondehem. Hälsingerunor 1953. 